\title{
Mentalna karta Europe: promjene u vizuri zagrebačkih srednjoškolaca (2000. - 2017.)
}

DOI: https://doi.org/10.11567/met.35.1.2

UDK: 316.64-057.84(4975):[314.15(4)

Prethodno priopćenje

Primljeno: 29.10.2019.

Prihvaćeno: 02.12.2019.

\section{Laura Šakaja}

Geografski odsjek, Prirodoslovno-matematički fakultet, Sveučilište u Zagrebu, Zagreb

Isakaja@geog.pmf.hr

\begin{abstract}
SAŽETAK
Rad se bavi slikom Europe zagrebačkih srednjoškolaca. Rezultati se temelje na anketnom istraživanju provedenom 2016. - 2017., koje je ponovilo istraživanje provedeno 2000. - 2001. (Śakaja, 2001; Šakaja i Mesarić, 2001; Šakaja, 2002). Ponavljanje istraživanja po istoj metodologiji i na sličnome uzorku omogućilo je longitudinalnu analizu predodžbe mladih Zagrepčana o Europi, odnosno europskim zemljama. U obradi podataka primijenjena je metodologija koju su predložili Peter Gould i Rodney White (1986). Rezultati su pokazali da je Europa na imaginativnoj karti obiju generacija mladih Zagrepčana jasno podijeljena na razvijeni Zapad i zaostali Istok. Obje su generacije percipirale Europu unutar binarnih opozicija. No znatan porast statusa Rusije upućuje na pomake unutar te binarnosti. Kvalitativna obrada odgovora na otvorena anketna pitanja pokazala je da nova generacija svoj izbor najpoželjnijih zemalja u najvećoj mjeri temelji na ekonomskim značajkama zemalja destinacije, za razliku od prijašnje generacije, koja je pri svojoj visokoj evaluaciji poželjnih zemalja nešto češće navodila kulturne razloge od ekonomskih. Sukladno tome $u$ razmišljanju o migracijskim odredištima unutar Europe kriterij pripadnosti tradicionalnim, povijesno uspostavljenim europskim kulturnim krugovima manje je relevantan nego prije, što je vidljivo iz relativnoga pada statusa mediteranskih zemalja, posebno Italije, kao poželjnoga odredišta za migraciju. Nasuprot tome porastao je stupanj poželjnosti sjevernih, osobito skandinavskih, zemalja. Jedna od najvećih sličnosti u rezultatima iz 2000./2001. i 2016./2017. jest pozicioniranje balkanskih zemalja, osobito Albanije, Srbije i Kosova, na samo dno liste prostornih preferencija - kako zbog percipiranih slabih ekonomskih značajki tih zemalja tako i zbog izrazitih, očito stabilnih, negativnih stereotipa.
\end{abstract}

KLJUČNE RIJEČI: Europa, mentalne karte, prostorne preferencije

\section{UVOD}

Prostorne prakse pojedinaca i prostorne društvene prakse velikim su dijelom oslonjene na subjektivno doživljavanje prostora. Predodžbe o prostoru, odnosno mentalne slike prostora, prostornim djelovanjem pojedinaca i grupa imaju itekako realne i opipljive geografske posljedice. Stoga je prouča- 
vanje percepcije odnosno imaginacije prostora već više od šezdeset godina integralan dio humane geografije. Iako je još do sredine 20. stoljeća sve što je vezano uz ljudsku prostornu imaginaciju u akademskoj geografskoj disciplini bilo potpuno nepoznato i neproučeno polje - terra incognita (Wright, 1947), već se 1952. u geografiji pojavljuje pojam »bihevioralni okoliš« (Kirk, 1989 [1952]) koji označava okoliš kako ga percipiraju i shvaćaju pojedinci i društvene skupine. Pojavljivanje toga pojma utvrdilo je u geografskoj znanosti razumijevanje činjenice da isti empirijski podaci mogu biti interpretirani na različit način i imati različita značenja za ljude različitih kultura ili u različitim povijesnim razdobljima (Kirk, 1963: 366). Potreba pak za znanstvenim proučavanjem ljudske prostorne percepcije i subjektivnog razumijevanja prostora izrasla je iz svijesti o tome da se osobe ne ponašaju u prostoru u skladu s objektivnim obilježjima toga prostora, nego u skladu s mentalnom imaginativnom slikom.

U posljednjim desetljećima dvadesetoga stoljeća interes za imaginaciju prostora rezultirao je mnoštvom istraživanja, među kojima valja istaknuti studije koje su se bavile percepcijom urbanih područja (Lynch, 1960), regija i država (Gould i White, 1974) te cijeloga svijeta (Saarinen, 1988; Saarinen i MacCabe, 1995; Bailly, MacCabe i Saarinen, 1995; André i Bailly, 1998).

Istraživanje koje će ovdje biti prezentirano na tragu je gore navedenih studija, a zasnovano je na metodologiji koju su opisali američki geografi Peter Gould i Rodney White u knjizi Mentalne karte (1974). U središtu su pozornosti prostorne preferencije ljudi, odnosno preferencijalna diferenciranost prostora. Gdje bi osobe i skupine osoba željele živjeti? Koji su prostori za njih ugodni ili neugodni, koja su mjesta poželjna ili nepoželjna za život? Odgovori na takva pitanja omogućuju da primjenjujući metodologiju Goulda i Whitea propitamo mentalne karte pojedinaca i ljudskih skupina.

U Hrvatskoj je proučavanje mentalnih karata toga tipa započelo 2000. 2001. u istraživanju »Mentalna karta Europe« (L. Šakaja). Svrha te studije bila je da se na uzorku srednjoškolaca propita slika Europe u predodžbama hrvatske mladeži. U prvoj fazi istraživanje je provedeno na zagrebačkom uzorku (Šakaja, 2001, 2002), dok je u drugoj fazi uzorak proširen na Split, Rijeku i Osijek (Šakaja, 2004; Šakaja i Mesarić, 2001). Nakon više od petnaest godina, 2016. - 2017., studija je ponovljena po istoj metodologiji, na sličnome uzorku, $\mathrm{u}$ ista četiri najveća hrvatska grada, a u ovome će se radu prezentirati rezultati koji su prikupljeni u Zagrebu te se odnose na mentalne karte zagrebačkih srednjoškolaca. Interes za ponavljanje istraživanja bio je potaknut dvjema činjenicama. Kao prvo, u razmaku između dviju stu- 
dija Hrvatska je postala članica Europske unije. Kao drugo, današnji srednjoškolci rodili su se nakon raspada Jugoslavije, osnutka hrvatske države i završetka Domovinskoga rata. Jesu li te okolnosti promijenile mentalne karte mladih? Jesu li ulaskom u EU modificirani stavovi o Europi? Koliko su predodžbe o Europi naraštaja koji nije doživio političke potrese i ratna zbivanja 1990-ih drugačije od predodžbi njihovih prethodnika? Upravo se na ta pitanja nastojalo odgovoriti ponavljanjem istraživanja i usporedbom rezultata iz 2000./2001. i 2016./2017.

\section{METODOLOGIJA ISTRAŽIVANJA}

Anketom u Zagrebu, kako 2000./2001. tako i 2016./2017., obuhvaćeni su završni razredi u ukupno šest škola s četverogodišnjim obrazovnim programom. Pri odabiru škola vodilo se računa o zastupljenosti škola različitih smjerova i veličina. $U$ oba istraživanja bili su uključeni učenici završnih razreda dviju gimnazija (XI. i IV.), triju tehničkih i srodnih škola (Tehnička škola Ruđera Boškovića, Škola za primalje i Privatna srednja ekonomska škola Katarine Zrinski) te jedne umjetničke škole (Glazbena škola Vatroslava Lisinskoga). U prvom je istraživanju dobiveno 395 valjanih anketa, dok ih je u drugome bilo 320. Razlog manjeg uzorka u drugoj studiji jest manji broj učenika u završnim razredima spomenutih škola u odnosu na vrijeme prethodnoga istraživanja. Ta činjenica, dakako, odgovara općenito kontinuiranom smanjenju broja učenika u hrvatskim školama u navedenom razdoblju. ${ }^{1}$

Bez obzira na to što se od početka vodilo računa o uravnoteženosti odabira »ženskih « $\mathrm{i}$ »muških « škola, među ispitanicima je bilo više djevojaka nego mladića. U uzorku istraživanja iz 2000./2001. bilo je 64,3\% djevojaka i $34,2 \%$ mladića; $1,5 \%$ ispitanika nije navelo svoj spol. U uzorku istraživanja iz 2016./2017. bilo je 62,8\% djevojaka i 36,9\% mladića, a 0,3\% (jedan ispitanik) nije navelo svoj spol.

Središnje pitanje ankete glasilo je: »Pretpostavite da možete slobodno birati u kojoj ćete europskoj zemlji živjeti. U kojim biste se zemljama najradije nastanili, a koje ne biste nikako izabrali za život?« Na popratnom popisu europskih zemalja ispitanici su trebali rangirati zemlje prema redoslijedu poželjnosti: zemlju u kojoj bi najradije živjeli trebali su označiti brojkom

Srednje škole i učenički domovi: kraj školske godine 2001/2002 i početak školske godine 2002/2003., Zagreb, Državni zavod za statistiku, 2003., i Srednje škole i učenički domovi: kraj školske godine 2016/2017 i početak školske godine 2017/2018., Zagreb, Državni zavod za statistiku, 2018. 
jedan, drugu po redu brojkom dva i tako dalje. S popisa europskih zemalja $\mathrm{u}$ oba su istraživanja izostavljeni Hrvatska i Vatikan. Uslijed promjena na političkoj karti Europe popis europskih zemalja predočenih učenicima bio je promijenjen i prilagođen aktualnom stanju: na popisu iz 2016./2017. nije više bilo Jugoslavije, a pojavile su se zemlje nastale njenim raspadom - Srbija, Crna Gora i Kosovo. Na popis zemalja dodan je i Cipar, čiji je ulazak u EU 2004. nedvojbeno pozicionirao tu zemlju u europski prostor.

Pojedinačna rangiranja učenika integrirana su u niz koji je pokazao opći trend $\mathrm{u}$ bodovanju zemalja. Kao što je gore već spomenuto, $\mathrm{u}$ obradi podataka primijenjena je metodologija koju su opisali Gould i White (1986: 157164), a riječ je o postupku utemeljenom na modifikaciji statističke tehnike poznate kao analiza glavnih komponenti. Primjena toga postupka omogućila je izračun za svaku zemlju zajedničkoga boda - rezultata spajanja individualnih procjena učenika o poželjnosti dotične zemlje kao eventualnoga životnog odredišta. ${ }^{2}$ Nakon dobivanja ukupnih bodova za sve europske zemlje, oni su bili, radi lakše primjene u sastavljanju karte, obrnuti i pretvoreni u skalirane bodove, tako da je zemlja bodovana s 1, dakle najpoželjnija za život, dobila skalirani bod 100, a zemlja bodovana s 45 (42 u prethodnom istraživanju), dakle najnepoželjnija za život, dobila je skalirani bod 0 . Tablica 1 sadržava upravo tako generirane skalirane bodove i prikazuje stupanj poželjnosti europskih zemalja za život iz perspektive mladih Zagrepčana.

2 Metodologija je detaljno objašnjena u knjizi Goulda i Whitea (1986), a opisana je također i u radu Sakaja i Mesarić (2001). Ovdje ćemo samo kratko izložiti postupak. Svaki od 320 ispitanika u istraživanju 2016./2017. rangirao je 45 zemalja s ponuđenoga popisa od 1 do 45 prema stupnju poželjnosti života u njima. Na osnovi toga sastavljena je tablica s 320 kolona (sukladno broju osoba) i 45 redaka (sukladno broju zemalja). Nakon toga izračunan je koeficijent korelacije između svih mogućih parova ispitanika te sastavljena korelacijska matrica $(320 \times 320)$. Svaka je varijabla korelacijske matrice (odnosno svaka osoba) u daljnjem postupku reprezentirana kao vektor. Kosinus kuta između dva vektora jednak je koeficijentu korelacije između odgovarajućega para varijabli (odnosno odgovarajućega para osoba). Na osnovi dobivenih vektora pronalazimo eigenvektor ili referentni vektor. Taj se referentni vektor mora nalaziti u takvoj poziciji da zbroj kvadrata kosinusa kutova što ih tvore individualni vektori s referentnim vektorom bude maksimalan. U takvu slučaju referentni vektor najbolje uopćava sve varijable (u našem slučaju referentni vektor predstavlja najtipičniju procjenu jedne europske zemlje od svih ispitanika). Kosinus kuta što ga tvori individualni vektor s referentnim vektorom pokazuje razliku stava pojedinoga ispitanika od najtipičnijega stava, odnosno opterećenje stava ispitanika. Što je veći kosinus što ga tvori individualni vektor s referentnim, to je stav ispitanika bliži tipičnomu stavu, odnosno njegovo je opterećenje veće. Umnoškom opterećenja (kosinusa kuta što ga individualni vektor čini s referentnim) i rednoga broja koji je ispitanik dodijelio zemlji dobivamo ponderiranu vrijednost boda te zemlje za svakog ispitanika. Ukupni bod za svaku zemlju jest zbroj svih 320 ponderiranih vrijednosti bodova ispitanika za dotičnu zemlju. 
Otvorena pitanja, također uključena $\mathrm{u}$ anketu, dala su uvid $\mathrm{u}$ argumente pri rangiranju pojedinih zemalja te otvorila mogućnost za razumijevanje diferenciranosti preferencijskoga prostora Europe.

Tablica 1. Stupanj poželjnosti za život europskih zemalja, 2000./2001. i 2016./2017.

Table 1. Level of preference to live in European countries, 2000/2001 and 2016/2017

2000./2001.

2016./2017.

\begin{tabular}{|c|c|c|c|}
\hline Bodovane zemlje & $\begin{array}{c}\text { Skalirani } \\
\text { bodovi zemalja }\end{array}$ & Bodovane zemlje & $\begin{array}{c}\text { Skalirani } \\
\text { bodovi zemalja }\end{array}$ \\
\hline Italija & 100,00 & Velika Britanija & 99,99 \\
\hline Francuska & 99,52 & Švicarska & 97,29 \\
\hline Velika Britanija & 97,31 & Njemačka & 97,14 \\
\hline Španjolska & 94,53 & Švedska & 90,66 \\
\hline Njemačka & 94,15 & Francuska & 90,38 \\
\hline Švicarska & 92,77 & Austrija & 90,14 \\
\hline Nizozemska & 88,26 & Irska & 86,52 \\
\hline Austrija & 87,23 & Norveška & 85,41 \\
\hline Monako & 81,00 & Nizozemska & 84,71 \\
\hline Portugal & 77,16 & Danska & 83,29 \\
\hline Irska & 76,27 & Italija & 82,47 \\
\hline Malta & 76,09 & Španjolska & 80,95 \\
\hline San Marino & 75,17 & Finska & 78,64 \\
\hline Belgija & 74,80 & Belgija & 76,99 \\
\hline Švedska & 73,94 & Portugal & 74,78 \\
\hline Danska & 72,90 & Luksemburg & 68,15 \\
\hline Luksemburg & 71,40 & Monako & 63,07 \\
\hline Norveška & 71,40 & Island & 60,74 \\
\hline Grčka & 66,26 & Češka & 59,50 \\
\hline Finska & 64,33 & San Marino & 55,05 \\
\hline Slovenija & 56,78 & Poljska & 53,26 \\
\hline Island & 56,04 & Malta & 52,47 \\
\hline Lihtenštajn & 54,14 & Rusija & 48,42 \\
\hline Češka & 50,35 & Lihtenštajn & 45,85 \\
\hline Andora & 49,11 & Slovenija & 43,62 \\
\hline
\end{tabular}


2000./2001.

\begin{tabular}{|c|c|c|c|}
\hline Bodovane zemlje & $\begin{array}{c}\text { Skalirani } \\
\text { bodovi zemalja }\end{array}$ & Bodovane zemlje & $\begin{array}{c}\text { Skalirani } \\
\text { bodovi zemalja }\end{array}$ \\
\hline Poljska & 40,79 & Mađarska & 40,34 \\
\hline Slovačka & 38,33 & Slovačka & 40,33 \\
\hline Mađarska & 35,45 & Estonija & 38,54 \\
\hline Estonija & 34,50 & Grčka & 38,46 \\
\hline Litva & 30,96 & Latvija & 35,76 \\
\hline Latvija & 29,96 & Litva & 35,65 \\
\hline Moldavija & 22,25 & Cipar & 34,41 \\
\hline Rumunjska & 20,88 & Andora & 33,57 \\
\hline Ukrajina & 19,95 & $\mathrm{BiH}$ & 24,76 \\
\hline Turska & 19,75 & Ukrajina & 23,38 \\
\hline Bugarska & 19,52 & Turska & 23,03 \\
\hline Rusija & 16,85 & Bjelorusija & 22,77 \\
\hline Bjelorusija & 15,58 & Bugarska & 21,74 \\
\hline Makedonija & 14,33 & Crna Gora & 20,12 \\
\hline $\mathrm{BiH}$ & 13,76 & Moldavija & 17,99 \\
\hline Albanija & 8,86 & Makedonija & 17,77 \\
\hline \multirow[t]{4}{*}{$\underline{\text { Jugoslavija }}$} & 0,00 & Rumunjska & 17,25 \\
\hline & & Srbija & 13,72 \\
\hline & & Albanija & 2,99 \\
\hline & & Kosovo & 0,00 \\
\hline
\end{tabular}

\section{NAJPOŽELJNIJE ZEMLJE ZA ŽIVOT - PROMJENE PREFERENCIJA}

Prije nego što pristupimo analizi prostornih preferencija zagrebačkih srednjoškolaca, valja napomenuti da usporedba rezultata istraživanja iz 2000./2001. i 2016./2017. upućuje na tendenciju rasta u planiranju preseljenja. Naime jedno od pitanja u istraživanju bilo je: „Što mislite, gdje ćete živjeti za pet godina?« Dok je 2000./2001. godine $22 \%$ anketiranih izjavilo da će za pet godina živjeti izvan Hrvatske, u 2016./2017. njihov broj narastao je i dosegnuo 35\%, što, dakako, korespondira s tendencijom povećanja realnih tokova iseljavanja iz Hrvatske (Draženović, Kunovac i Pripužić, 2018; Balija, 2019).

Koje zemlje mladi smatraju najpoželjnijima za život? Najprije ćemo se zadržati na rezultatima studije iz 2000./2001. (Šakaja, 2001, 2002). 
Slika 1. Stupanj poželjnosti europskih zemalja za život, 2000./2001.

Figure 1. Level of preference to live in European countries, 2000/2001

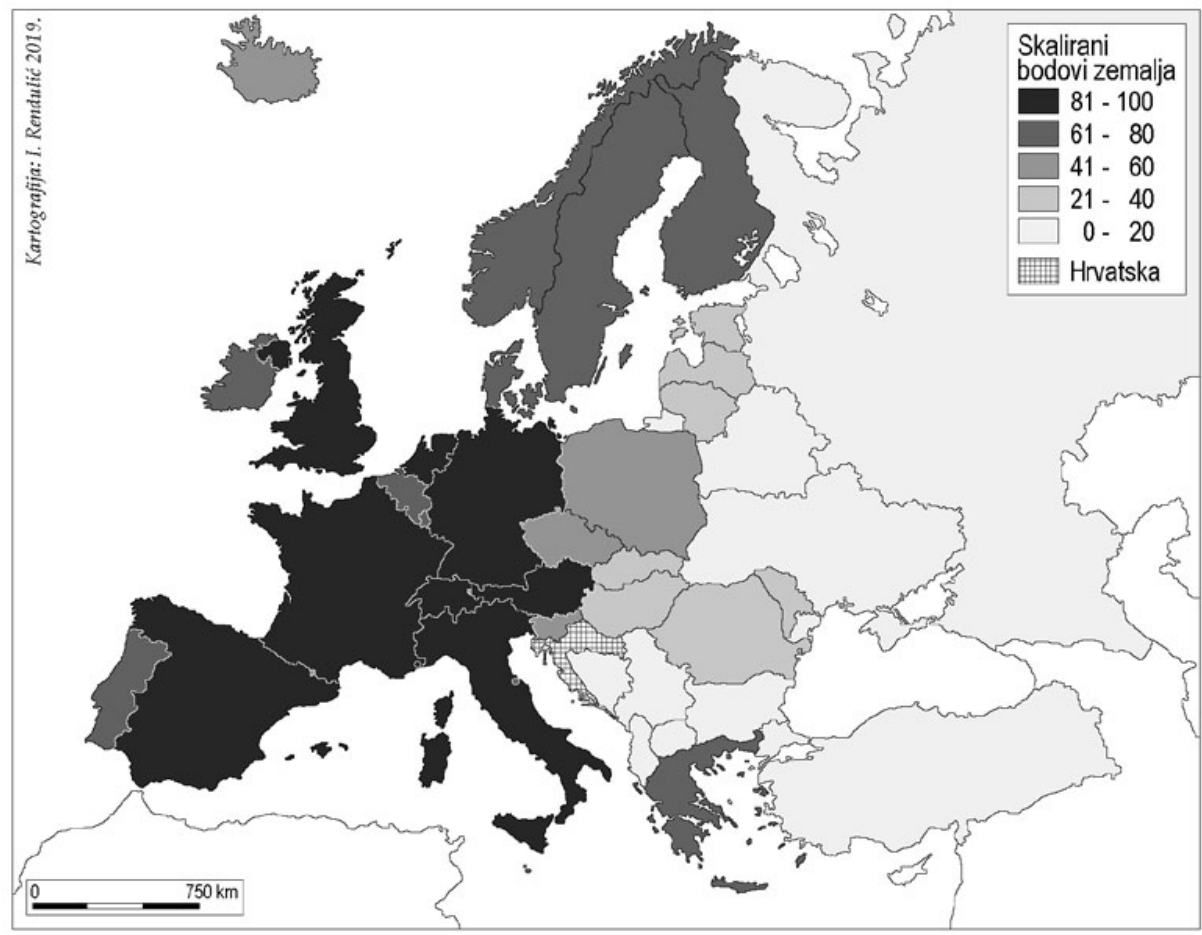

Kako proizlazi iz stavova ispitanih zagrebačkih srednjoškolaca, najpoželjnije za život na početku milenija bile su sljedeće zemlje (prema redoslijedu poželjnosti): 1. Italija, 2. Francuska, 3. Velika Britanija, 4. Španjolska, 5. Njemačka, 6. Švicarska, 7. Nizozemska, 8. Austrija, 9. Monako, 10. Portugal. Analizirajući te podatke, možemo uočiti fenomen koji su Gould i White nazvali »razmišljanje $u$ okviru granica« (boundary thinking). Naime njihova su istraživanja mentalnih karata europskih stanovnika, provedena 1960-ih, pokazala da su, gledano iz perspektive Nijemaca, najpoželjnije zemlje za stanovanje Austrija, Švicarska, Nizozemska, Danska i Švedska, dakle germanske zemlje, a gledano iz perspektive Italije, najpoželjnije su zemlje u kojima se govori romanskim jezicima - Španjolska i Portugal. Gould i White zaključuju da modeli razmišljanja mnogih Europljana i dalje odražavaju stare granice. Možemo reći da mentalne karte učenika u istraživanju iz 2000./2001. potpuno odgovaraju takvim obrascima. Naime $u$ anketama vidimo da je od deset najpoželjnijih zemalja osam pripadalo mediteranskome ili srednjoeuropskome kulturnome krugu, preko kojih je, kao što je poznato, i Hrvatska definirala svoj identitet. 
Na samome vrhu liste preferencija našlo se pet romanskih (mahom mediteranskih) i pet germanskih zemalja. Pritom je zanimljivo da se odnos prema njima pokazao vrlo diferenciranim (Šakaja, 2002: 126). Pri ocjeni romanskih zemalja kao vrlo poželjnih za život važnima su se pokazali čimbenici vezani uz kulturnu, društvenu i prirodnu sredinu. Kao ključni navodili su se kulturni i povijesni elementi (jezik, način života, običaji, nasljeđe, tradicije, arhitektura, ambijent gradova, kulturni krajolici i moda), prirodni čimbenici (klima, sunce i more), mentalitet stanovnika (»srdačnost«", "pristupačnost«, »ljubaznost «, »opuštenost «i sl.). Odnos prema germanskim zemljama s vrha liste poželjnosti pokazao se znatno drugačijim. Riječ je o pragmatičnijem pristupu, čiju su osnovu, kako se moglo zaključiti iz ankete, činili ekonomski elementi - visok životni standard, mogućnost zaposlenja i visoke plaće.

Zanimljivo je usporediti argumentaciju u odabiru kao poželjnih dviju zemalja - Italije, za Hrvate najvažnije emigracijske destinacije među romanskim zemljama, i Njemačke - najvažnije emigracijske destinacije među germanskim zemljama.

Italija se našla se na samome vrhu po stupnju poželjnosti, a na osnovi odgovora na otvorena anketna pitanja možemo zaključiti da ju je takvom činio spektar elemenata vezanih uz kulturu i povijest, prirodu, gospodarstvo i ljude. Anketirani sudionici istraživanja opisivali su je sljedećim karakteristikama: »tradicija još od starih Rimljana «, »stara i bogata povijest «, »mediteranski način života«, »način života relativno ležeran, mada živahan i brz«, »sličnost s Dalmacijom «, »lijepi jezik «, »talijanska hrana«, »visoka moda«, »klima«, »more«, »planine«, »razvijeno, stabilno gospodarstvo«, »industrija «, »mogućnosti za razvijanje privatnoga biznisa «, »visoki standard «, »obilje radnih mjesta«, »otvorene mogućnosti za mlade« te »komunikativni«, »otvoreni«, »bezbrižni«, »jednostavni«, »temperamentni«, »neopterećeni poslovnim obvezama «, ljudi koji imaju »smisao za estetsku i za humor«. Kao važne činjenice navođene su »sličnost s Hrvatskom«i teritorijalna »blizina Hrvatskoj« (v. Šakaja, 2002).

$S$ druge strane, argumentacija kojom se obrazlagala atraktivnost Njemačke bila je vrlo jednostrana i pragmatična. Čak $63 \%$ razloga pri odabiru Njemačke činili su ekonomski razlozi. Drugu po značenju grupu razloga - njih $9 \%$ - činili su oni također vrlo praktične naravi - riječ je bila uglavnom o lakšoj adaptaciji zahvaljujući rodbini nastanjenoj u Njemačkoj (v. Šakaja, 2002).

Uspoređujući argumente kojima su se koristili ispitanici, čini se da možemo primijetiti naznake dihotomije između romantizirajućega odnosa prema romanskim mediteranskim zemljama i racionalizirajućega odnosa prema 
germanskim zemljama, prisutne u mentalnim kartama mladih Zagrepčana na početku milenija.

Slika 2. Stupanj poželjnosti europskih zemalja za život, 2016./2017.

Figure 2. Level of preference to live in European countries, 2016/2017

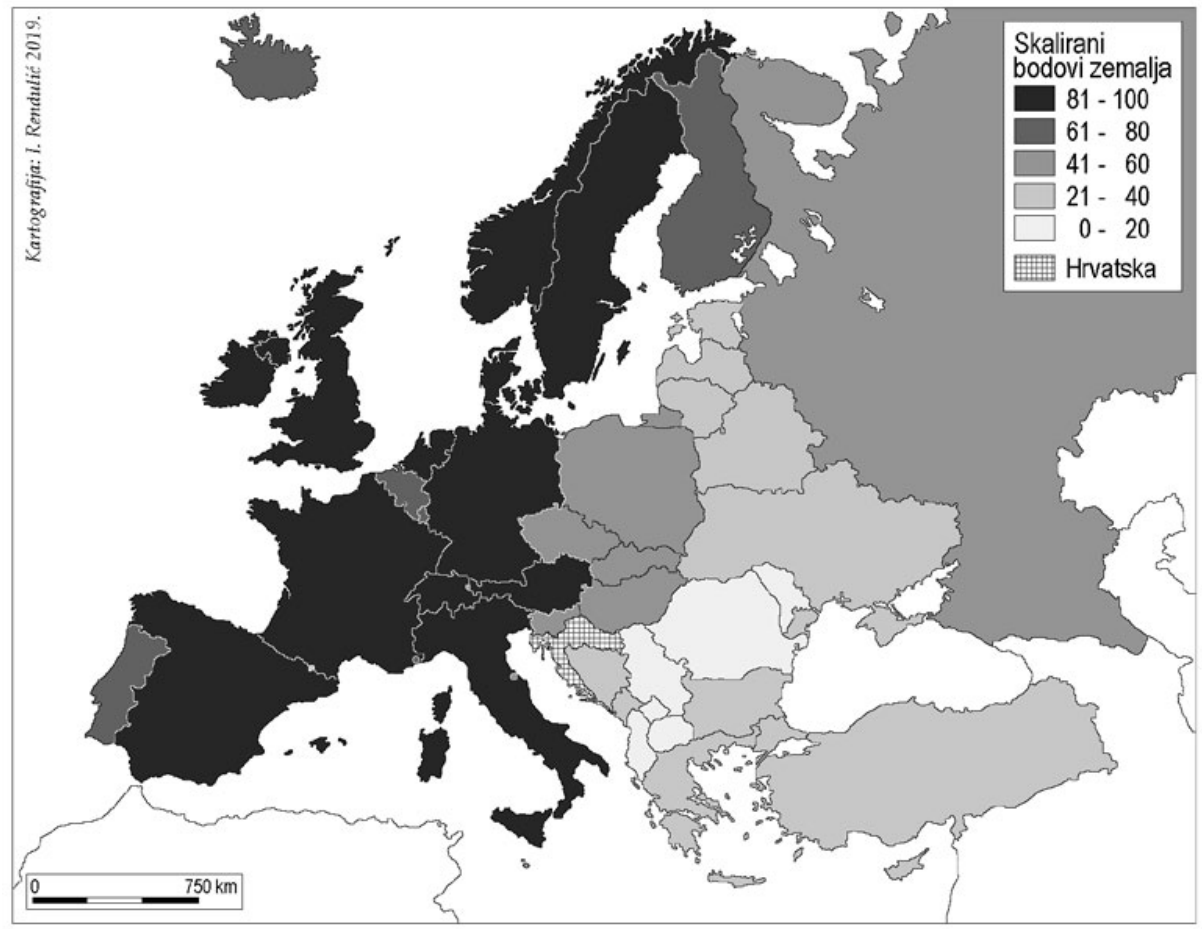

Podaci istraživanja iz 2016./2017. upućuju na promjenu prostora preferencija. I dalje se među najpoželjnijima za život nalaze srednjoeuropske zemlje Njemačka, Austrija i Švicarska. No od mediteranskih je zemalja među prvih deset najpoželjnijih ostala samo Francuska. Italija je pala s 1. na 11. mjesto, Španjolska s 4. na 12., Monako s 9. na 17., Portugal s 10. na 15. S druge strane, $u$ deset najpoželjnijih ušle su jedna zapadna i tri sjeverne zemlje Irska, Švedska, Danska i Norveška. Dakle među zemljama koje su sada popularnije nego što su bile početkom milenija veći dio čine sjeverne zemlje - Švedska, Norveška, Finska, Danska i Island - te jedna zapadna - Irska. S druge strane, na statusu poželjnosti najviše su izgubile južne mediteranske zemlje - Grčka, Italija, Španjolska, Portugal, Monako, Malta i San Marino. Te mediteranske zemlje činile su čak 70\% zemalja čiji je status od 2001. do 2017. pao (v. slika 3). 
Slika 3. Zemlje s najvećom promjenom stupnja poželjnosti

Figure 3. Countries with the largest shift in level of preference

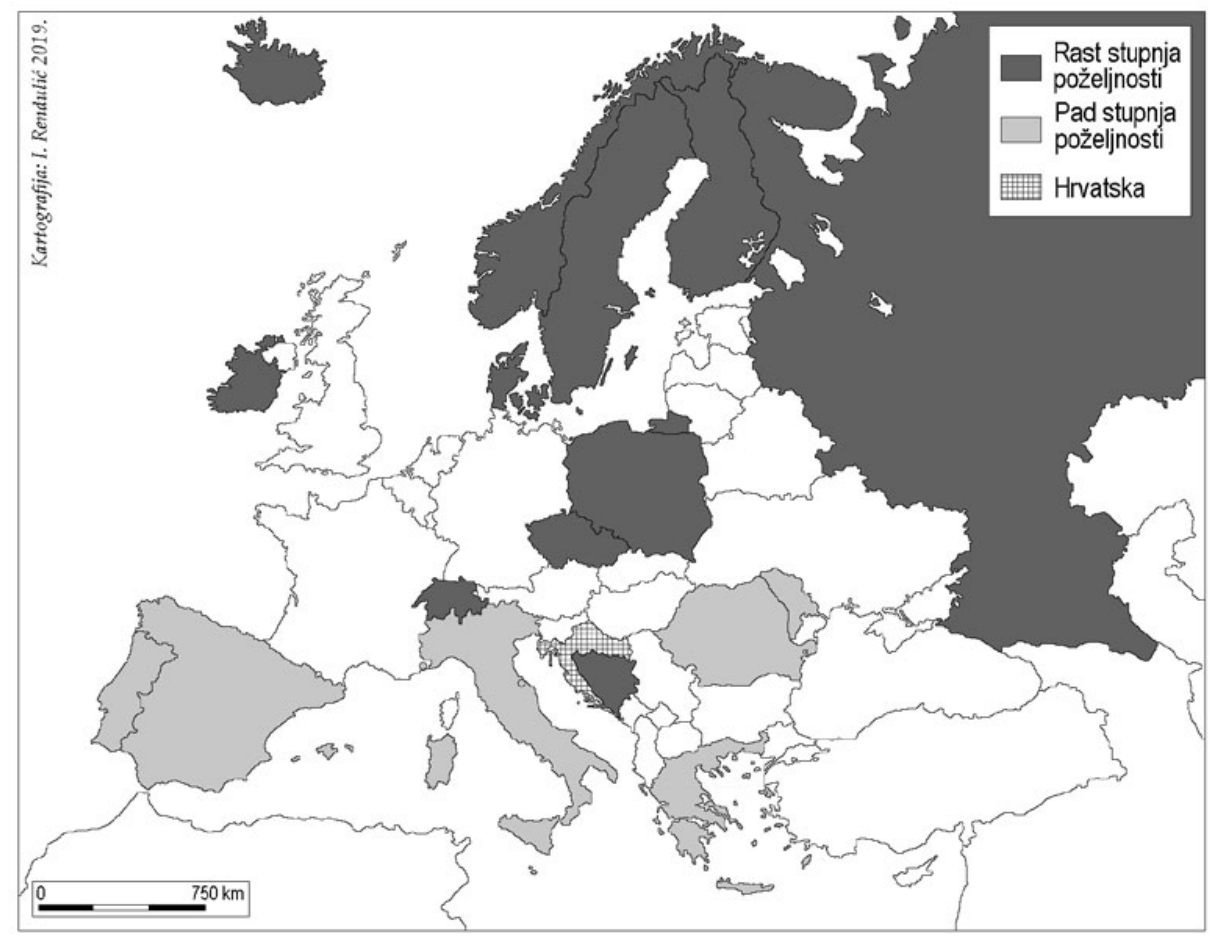

Razmišljajući o razlozima povećanja statusa sjevernih zemalja kao poželjnih migracijskih destinacija, možemo pretpostaviti da nova generacija svoj izbor najpoželjnijih zemalja u većoj mjeri temelji na ekonomskim značajkama zemalja destinacije. Kvalitativna obrada odgovora na otvorena pitanja (vidi sljedeće poglavlje) potvrđuje plauzibilnost te pretpostavke, a njoj u prilog ide i činjenica da korelacija između rang-liste zemalja po poželjnosti i rangliste zemalja po BDP-u po stanovniku iznosi 1, dakle je iznimno visoka.

Moguće je također da sjeverne zemlje postaju za mlade privlačnijima za život nego što su bile prije pod utjecajem rasprava o klimatskim promjenama i globalnome zatopljenju. Podaci istraživanja ne daju jasne argumente za tu tezu, ali primjećujemo da su »hladnije vrijeme«, »snijeg «, »malo sunca« i sl. neki ispitanici doista navodili kao element atraktivnosti skandinavskih zemalja.

Među deset najviše rangiranih zemalja bila je i Velika Britanija. S četvrtoga mjesta 2000./2001. popela se na prvo 2016./2017., dakle bila je po- 
zicionirana kao najpoželjnija za život europska zemlja. U osnovi odnosa prema toj zemlji vrlo se jasno ističe engleski jezik. Sudeći po anketi, zemlja čiji se jezik najbolje zna čini se poznatijom, a njena kultura bližom. A prepoznavanju društvenoga, kulturnog i prirodnog okoliša te zemlje svakako su pridonijele brojne književne i filmske reprodukcije »ljepota engleskih krajolika«, »britanskoga stila « $\mathrm{i}$ »engleskoga načina života «, koji se često spominju $u$ anketama u pozitivnom kontekstu. Dobro poznavanje jezika zemlje potiče mišljenje o boljim vlastitim izgledima u školovanju, zapošljavanju i uspješnom uklapanju u društvo. Ukratko, mjesto Velike Britanije u mentalnim kartama, primarno zbog engleskoga jezika, a preko njega i engleske kulture, zasigurno nadilazi uočenu shemu romansko/ germanske dihotomije.

\section{POMAK PREMA PRAGMATIČNIJEM RAZMIŠLJANJU}

Kako bismo razumjeli smjer razmišljanja anketiranih učenika, obratimo se odgovorima na otvorena anketna pitanja. Naime ispitanici su bili zamoljeni da objasne odabir triju prvih i triju zadnjih zemalja na rang-listi, pa smo tako dobili i razloge njihova izbora. Te razloge, bez obzira na njihovu različitost, moguće je klasificirati u nekoliko grupa. Argumenti koje su ispitanici upotrijebili u oba istraživanja razvrstani su u sljedeće grupe.

1. Mogućnosti posla, ekonomski uvjeti i razvijenost gospodarstva. Ta je grupa izdvojena na osnovi izraza kao što su »bogata zemlja«, »razvijena zemlja «, »razvijeno gospodarstvo«, »visok standard «, »ekonomska stabilnost «, "prilike za zapošljavanje«, "poslovne mogućnosti«, »mogućnost karijere«, »materijalna sigurnost«, »dobre plaće«, »nema problema nezaposlenosti«, »novac« i slično. A s druge strane su negativni argumenti poput »slabo gospodarstvo «, »nerazvijenost «, »siromaštvo«, »teški uvjeti za pronalazak posla«, »teška ekonomska situacija« i sl.

2. Politička i socijalna sigurnost i sloboda. Najčešće spominjane formulacije iz ove grupe bile su: »demokratska zemlja «, »liberalnost«, »mirna zemlja«, "dobra politička organizacija ", "sposobni političari«, "nema sukoba«, »nema kriminala«, »neutralnost«, »politička stabilnost i sigurna budućnost «, »pravni sustav «, »sloboda «, »legalizirana laka droga « $\mathrm{i} »$ legalizirana marihuana «. Odnosno, s druge strane, »nesigurnost«, »politička nestabilnost «, »visoka stopa kriminala «, »problemi s migrantima«, »stalni nemiri«, »ratovi«, »politički kaos«, »mafija, droge i oružja«, »nesigurnost zbog terorističkih napada«i sl. 
3. Kultura, način života, centralnost i urbane funkcije. Unutar te skupine najčešće su spominjane riječi poput: »kultura«, »bogata povijest «, »način života«, »stil života«, »običaji«, »lijep jezik«, »znamenitosti«, »mediteranska zemlja«, "skandinavska zemlja «, "gradovi«, "arhitektura «, "moda«, »ugledna sveučilišta « $\mathrm{i} »$ dobri fakulteti«. Faktor kulture navodio se i u negativnom registru kao »drugačiji svjetonazor «, »drugačiji način života«, »ružan jezik« i sl.

4. Etnopsihološki faktori. Pri obrazlaganju želje za životom u određenim zemljama vrlo su često upotrebljavane riječi poput »ljudi «, »narod «, »stanovništvo« $\mathrm{i}$ »mentalitet «, uz varijacije - »komunikativni ljudi«, »intelektualna nacija «, »raznolikost stanovništva«, »ljubaznost ljudi «, »opuštenost ljudi «, »dobroćudni ljudi«, »simpatični«, »pristojni«, »dobar moral« itd. S druge strane, pri obrazloženju negativnoga stava također su se navodile pretpostavljene negativne karakteristike stanovnika pojedine zemlje: "primitivni ljudi «, »drugačiji mentalitet «, »konzervativan i neintelektualan narod «, »zaostalost ljudi «, »čudan narod «, »opasan narod « i sl.

5. Prirodni faktori. Najčešće spominjani faktori u toj grupi bili su: »prirodne ljepote«, »lijep krajolik «i »klima«. Pritom se topla klima uglavnom spominjala u pozitivnom kontekstu, dok se u odnosu na niske zimske prosječne temperature mogla zapaziti podijeljenost mišljenja - neki su sudionici istraživanja doživljavali hladne zime kao negativnu okolnost, a drugi kao pozitivnu.

6. Blizina. Kao jedan od faktora poželjnosti zemalja za život spominjala se blizina domovini. U obrazloženju atraktivnosti blisko smještenih zemalja pojavljivale su se sintagme poput »blizu doma«, »povezanost s rodnom zemljom«, »nedaleko od Hrvatske«, »mogućnost posjećivanja rodbine zbog male udaljenosti« i sl. S druge strane, »udaljenost od Hrvatske« spominjala se kao negativan argument.

7. Osobni razlozi. U tu su grupu ušli prvenstveno argumenti kao što je postojanje rodbine ili prijatelja u određenoj zemlji, odnosno poznavanje jezika zemlje. Sestra, brat, stric, »familija«, »bliža rodbina«, »ostatak obitelji«, »imam rođaka «, odnosno dobro poznavanje jezika ili učenje jezika, sudeći po svemu, bitni su elementi u razmišljanju o eventualnom preseljenju.

8. Nespecificirani razlozi, poput »nije privlačna«, »čudna je«, »ne sviđa mi se«, ili pak oni sa suprotnim predznakom: »simpatična zemlja «, »sviđa mi se«, »znatiželjan sam prema toj zemlji«, izdvojeni su u posebnu grupu općih razloga. U tu su grupu bile uključene i izjave o stupnju informiranosti 
o zemlji. Dio ispitanika izravno je povezivao mogućnost preseljenja u neku zemlju s činjenicom da tu zemlju dobro poznaje. S druge strane, mnogi su upravo neinformiranost o zemlji naveli kao razlog njene vrlo niske ocjene kao mjesta za život.

Usporedbom podataka dvaju istraživanja možemo uočiti znakovite promjene.

Slika 4. Frekventnost razloga navedenih pri izboru najpoželjnijih zemalja za život (\%)

Figure 4. Frequencies of reasons of selecting the most preferable countries to live in $(\%)$

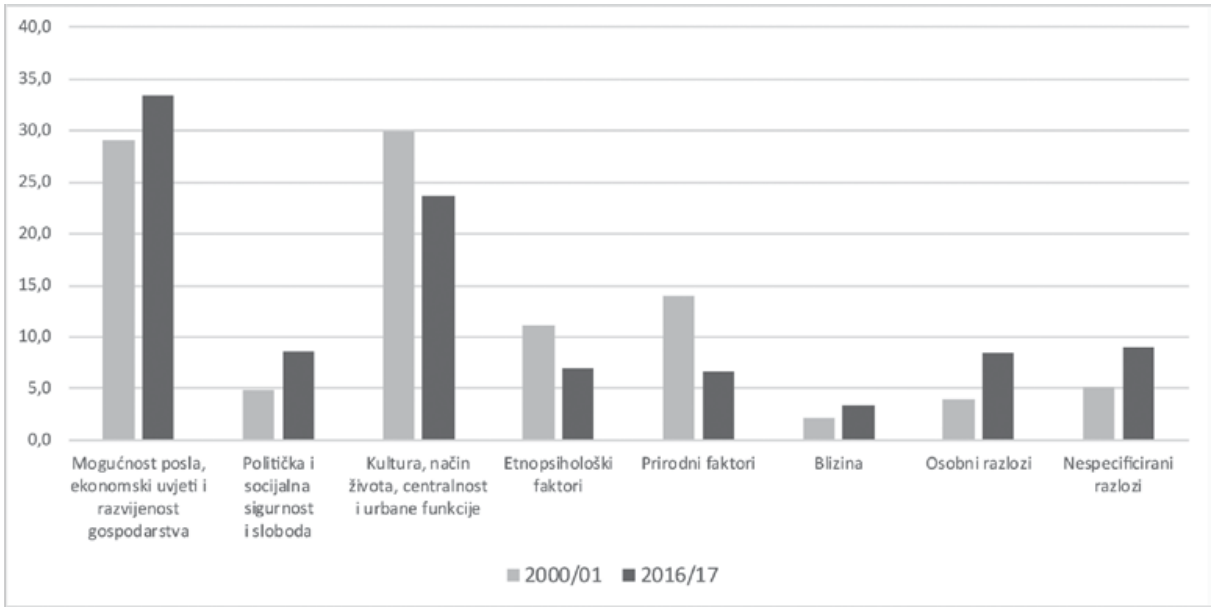

U odabiru zemalja za moguće preseljenje danas dominiraju ekonomski razlozi (slika 4). Dakle najbrojniji su argumenti vezani uz mogućnost posla, ekonomske uvjete i stupanj razvijenosti zemlje. Pritom je njihov udio u svim navedenim razlozima atraktivnosti zemalja povećan te je više od $33 \%$ svih argumenata kojima se obrazlagao visoki stupanj poželjnosti zemlje 2016./2017. bilo pragmatično-ekonomske naravi: ekonomska stabilnost zemlje, mogućnost pronalaska posla u struci, visoke plaće i sl. Taj nalaz svakako korespondira s već spomenutom činjenicom da između ranga zemalja po stupnju poželjnosti i ranga zemalja po BDP-u po stanovniku postoji vrlo visoka korelacija.

Drugu najfrekventniju grupu čine argumenti vezani uz kulturu, način života, centralnost i urbane funkcije. Pritom usporedba podataka dvaju istraživanja pokazuje da se udio važnosti čimbenika poput kulture, tradi- 
cije, nasljeđa i bogate povijesne baštine smanjio (s 30\% na 24\%), pa nova generacija vrednuje te osobine slabije nego njihovi prethodnici, koji su najviše argumenata za privlačnost zemalja navodili upravo $u$ toj sferi. $U$ vrednovanju zemalja smanjila se i uloga prirodnih čimbenika, osobito onih vezanih uz mediteransko podneblje - sunčana topla klima i more. A kao manje važne nova generacija vidi i etnopsihološke čimbenike - percipirane karakteristike stanovnika. Naime sintagme poput »blizak mentalitet «, »sličan mentalitet «, »srdačnost «, »opuštenost « itd. u novijem su istraživanju znatno rjeđe navođene kao argument privlačnosti zemlje nego $\mathrm{u}$ prethodnome.

Na osnovi podataka, kako se čini, moguće je donijeti zaključak da mladi Zagrepčani, barem oni koji su bili uključeni $u$ istraživanje, pristupaju preseljenju u neku od europskih zemalja pragmatičnije od prethodne generacije. U usporedbi s generacijom srednjoškolaca na početku milenija oni više vode računa o ekonomskom prosperitetu i gospodarskoj (a i političkoj) stabilnosti zemlje, a manje o okolišu prihvatne zemlje s njegovim kulturnim, društvenim i prirodnim obilježjima. Njihove prostorne preferencije zasnovane su na racionalnijoj i pragmatičnijoj te manje emocionalnoj i kulturno utemeljenoj motivaciji.

\section{NEPOŽELJNI PROSTORI EUROPE}

Kada je riječ o najnepoželjnijim zemljama za život, u njihovu su odabiru, kao i u odabiru poželjnih zemalja, u najvećoj mjeri sudjelovali ekonomski faktori (slika 5). Oni su činili 30\% u 2000./2001. i 28\% u 2016./2017. od svih ukupno nabrojenih argumenata protiv života u dotičnim zemljama. Vrlo je visok bio broj nespecificiranih razloga, osobito u istraživanju 2016./2017. Riječ je o sintagmama poput »ne odgovara mojim planovima za budućnost «, »nemam što raditi tamo«, »ne privlači me«, »ne sviđa mi se«, »ružna zemlja«, »užas«, »loša situacija općenito« i sl. Obilje tako općenitih argumenata svjedoči o činjenici da se negativni stav o zemlji ne generira nužno na osnovi konkretnih spoznaja o njoj. Tu tezu potkrjepljuje i činjenica da je većinu zemalja na dnu liste preferencija posjetilo manje od $5 \%$ anketiranih učenika. 
Slika 5. Frekventnost razloga navedenih pri označavanju zemalja kao najnepoželjnijih za život (\%)

Figure 5. Frequencies of reasons of selecting the least preferable countries to live in $(\%)$

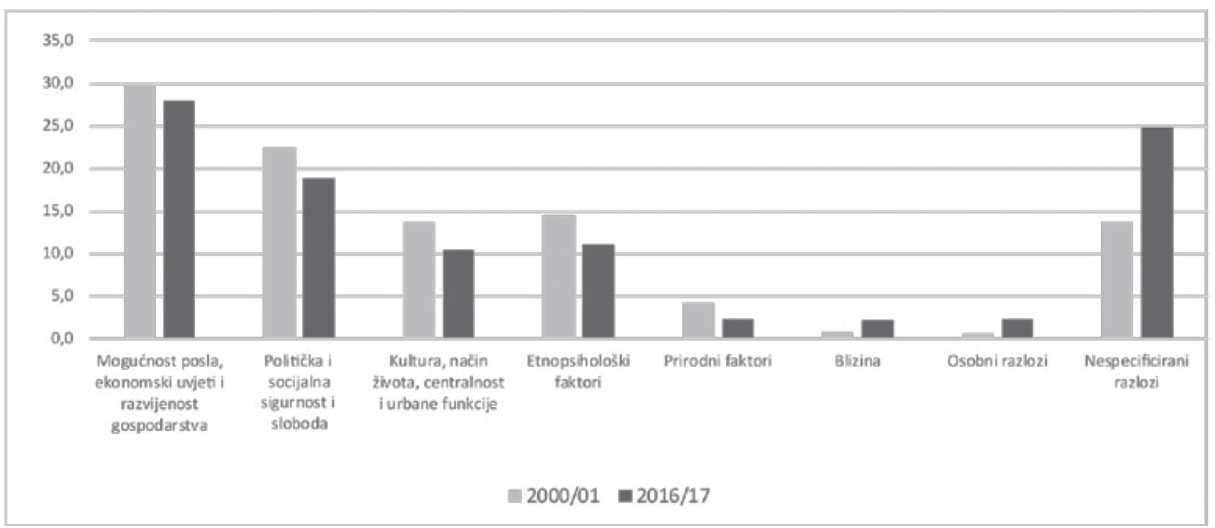

Početkom milenija na samome dnu liste nalazile su se Jugoslavija i Albanija. Kao što vidimo, to se nije promijenilo, te su se na dnu rang-liste 2016./2017. našle ponovno Albanija i dvije zemlje nastale raspadom Jugoslavije - Srbija i Kosovo. Kako bismo razumjeli negativan stav prema životu u tim zemljama, razmotrit ćemo argumente njihova svrstavanja na kraj liste poželjnosti europskih zemalja. Zanimljivo je da je odnos prema Kosovu i Albaniji gotovo identičan (slika 6). Najčešće spominjani pojmovi povezani s tim zemljama bili su »nerazvijenost«, »slabo gospodarstvo«, »kriminal « i »nesigurnost«, a uz Kosovo i »nestabilnost « te »sukobi«. Za razliku od njih, odnos prema Srbiji i dalje je, više od dvadeset godina nakon završetka Domovinskoga rata, definiran njegovim tragovima. Srbija je jedina zemlja na popisu europskih zemalja $u$ odnosu prema kojoj su dominirali etnopsihološki argumenti. Spominjali su se »(skroz drugi) mentalitet «, »način ponašanja«, »loš odnos prema Hrvatskoj i Hrvatima«, »animozitet između naših naroda«, »netrpeljivost«, »razilaženje u kulturi mišljenja« i »etničko neslaganje«. Neki su ispitanici navodili kao razlog nepoželjnosti života $u$ Srbiji »mržnju prema Hrvatima od strane nekih stanovnika«i »neljubaznost ponekih ljudi«. Iako su u nekim anketama sadržani ksenofobni komentari poput »loši ljudi «, »primitivni«, »četnici«, »nemoralni «i »pokvareni«, takvi su komentari, za razliku od komentara u prethodno provedenome istraživanju, bili rijetki, pa usporedbom tekstualnih dijelova anketa provedenih 2000./2001. i 2016./2017. možemo konstatirati redukciju ksenofobnih tonova $\mathrm{u}$ retorici prema nedavnom neprijatelju $\mathrm{u}$ ratu. 
Slika 6. Frekventnost razloga navedenih pri označavanju Kosova, Albanije i Srbije kao najnepoželjnijih zemalja za život (\%)

Figure 6. Frequencies of reasons of selecting Kosovo, Albania and Serbia as the least preferable countries to live in (\%)

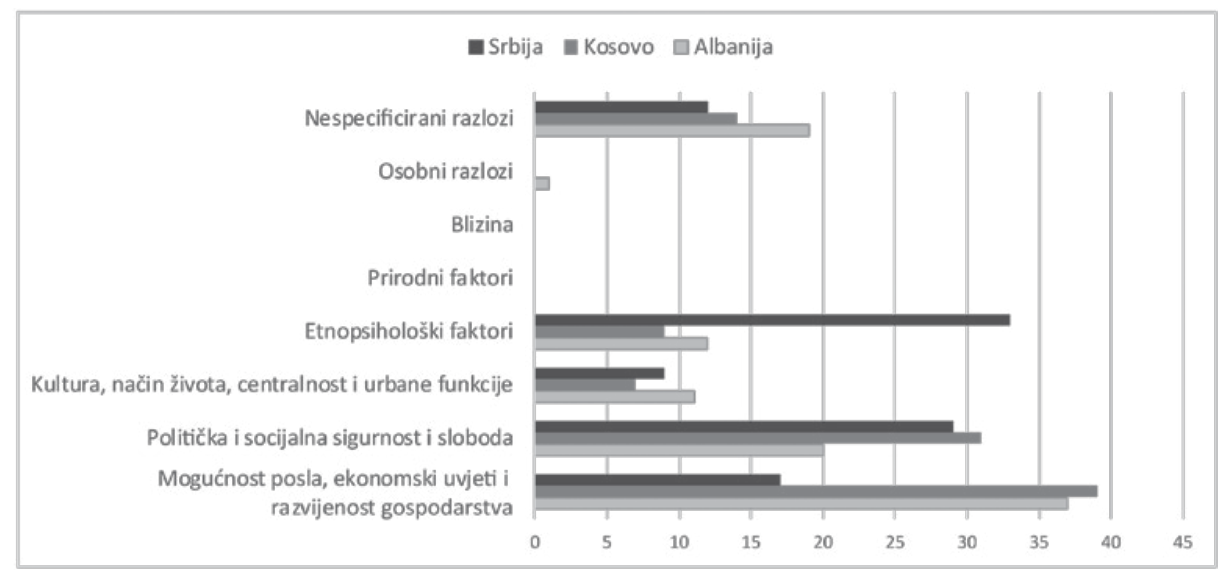

Ako pogledamo i druge zemlje $\mathrm{u}$ donjem djelu rang-liste poželjnosti zemalja za život, vidimo da se gotovo sve nalaze na Balkanu - uz Kosovo, Albaniju i Srbiju tu su Rumunjska, Makedonija, Crna Gora, Bugarska i Turska. Jedna od najvećih sličnosti u rezultatima istraživanja iz 2000./2001. i 2016./2017. jest to da se na samome dnu liste zemalja po poželjnosti za život nalaze balkanske zemlje. Od dvanaest zemalja koje su u novijem istraživanju dobile manje od 25 bodova devet ih je s Balkanskoga poluotoka. Stabilno pozicioniranje Balkana na dno ljestvice preferencija, kako možemo pretpostaviti, određeno je nižim ekonomskim značajkama većine zemalja s toga područja u odnosu na ostatak Europe te reproduciranjem izraza »Balkan« kao dugotrajnoga negativnoga stereotipa, uz ulogu Balkana kao konstituirajućega Drugoga (Todorova, 1996, 1997) Hrvatske u odnosu na koji se događa njeno odmjeravanje i izgrađuje identitet (Šakaja, 2001).

\section{EUROPSKI ZAPAD I ISTOK - BINARNOST MENTALNE KARTE}

Rezultati istraživanja iz 2000./2001. jasno su pokazali binarnost odnosa prema Istoku i Zapadu Europe. Izraz »Istok « često se pojavljuje u odgovorima na otvorena pitanja upitnika - $\mathrm{u}$ izjavama poput: »zemlje na Istoku me ne zanimaju «, »ne vuče me ništa na Istok «, "previše istočno za moj pojam « itd. Izraz »Zapad «s druge se strane upotrebljava kao argument pozitivnog stava prema nekoj zemlji - kao argument koji ne treba daljnje objašnjenje. 
Analiza odgovora na otvorena pitanja u upitniku pokazala je da Europa nije samo mentalno podijeljena na Zapad i Istok, nego je i percipirana $\mathrm{u}$ smislu binarnih opozicija. Rekonstruiran iz tekstova upitnika iz 2000./2001., sustav suprotstavljanja Zapada i Istoka na imaginarnoj karti Europi izgleda ovako (Šakaja, 2004: 303) (tablica 2).

Tablica 2. Percepcija Europe unutar binarnih opozicija

Table 2. Perception of Europe using the binary oppositions

\begin{tabular}{ll}
\hline Europski Zapad & Europski Istok \\
\hline ekonomski prosperitet & siromaštvo \\
\hline demokracija & ostaci socijalističkog poretka \\
\hline vladavina prava & sputavanje sloboda \\
\hline liberalnost & kriminal, korupcija \\
\hline sređenost & nesređenost (»kaos«) \\
\hline efikasnost & neefikasnost \\
\hline širok spektar mogućnosti & »nemogućnost ničega« \\
\hline modernost & zaostalost \\
\hline centralnost & perifernost \\
\hline uzbudljivost & nezanimljivost \\
\hline čisto & prljavo \\
\hline ljubazni ljudi & čudni, neljubazni i »zatucani« ljudi \\
\hline
\end{tabular}

Naravno, navedene binarne opozicije najizraženije su na polovima preferencija, tj. između najpoželjnijih i najmanje poželjnih zemalja. Ipak, bez obzira na razlike $u$ odnosu prema pojedinim zemljama, ima razloga za zaključak da se Zapad i Istok Europe percipiraju kao dvije zasebne cjeline, a navodne karakteristike pojedinih zemalja često generaliziraju i primjenjuju na druge zemlje unutar istog entiteta. $U$ mentalnim kartama prostori se vrijednosno kodiraju. Jedna te ista pojava može se protumačiti pozitivno ili negativno, ovisno o tome kojem se prostoru (pozitivno ili negativno percipiranom) pripisuje. Na primjer blizina Hrvatskoj može se tumačiti kao pozitivan ili negativan čimbenik s obzirom na to o kojoj je zemlji riječ. Plaže i obala te ugodna klima cijene se u Italiji, Španjolskoj, Monaku i na Malti. No nijedan od ispitanika nije se sjetio činjenice da je i Turska sunčana i topla. Niske temperature u slučaju Rusije plaše, a u slučaju Finske, Švedske, Norveške ili Islanda upućuju na »zanimljivu klimu«i »interesantan život u zimskom razdoblju«. Sudeći prema tekstovima ispitanika, dobra zabava 
može se pronaći u Parizu, Barceloni i Londonu, ali ne i u Bukureštu ili Tirani, a ljubazni, temperamentni, opušteni ljudi mogu se naći samo sa zapadne strane bivše željezne zavjese.

Kao što pokazuju rezultati istraživanja, Europa je i dalje jasno mentalno podijeljena na Zapad i Istok (slika 1 i slika 2). No možemo uočiti i naznaku pomaka u toj binarnosti, i to u drastičnom rastu statusa Rusije. Najveća promjena mjesta na rang-listi poželjnosti za život dogodila se upravo u slučaju Ruske Federacije. Naime Rusija se s 37. mjesta na rang-listi premjestila na 23. mjesto. Na ljestvici poželjnosti za život ona je skočila za četrnaest mjesta i našla se točno na sredini - kao 23. zemlja po poželjnosti od njih ukupno 45. Pritom vidimo da je odnos prema toj zemlji vrlo podijeljen. Ona se doživljava i u pozitivnom svjetlu, preko parametara kulturnog identiteta (»kultura«, »raznolikost zemlje«, »duša«, »način života «, »jezik« i »mentalitet«), i u negativnom svjetlu - preko predodžbe o hladnoj klimi (»zima«, »hladno« i »vrijeme«) i slabijem gospodarstvu (»nerazvijenost«, »siromaštvo« i »bijeda«). Vojna moć Rusije, kako se vidi, dio mladih ushićuje (»moćna velesila« $\mathrm{i} » j a k a$ vojna sila «), a dio zastrašuje (»militaristički i ekspanzionistički sustav« i »prijetnja nuklearnog rata«). Gledano politički, Rusija se opisuje pozitivno - kao »progresivno konzervativna zemlja«, ili negativno - kao zemlja u kojoj vladaju »politička ograničenja $\ll \mathrm{i} »$ neliberalni politički sustav«.

Ukratko, Europa na imaginativnoj karti mladih i dalje je podijeljena na razvijeni Zapad i zaostali Istok, no jasne promjene u percepciji Rusije upućuju na pomake unutar te binarnosti.

\section{ZAKLJUČAK}

Ponavljanje 2016./2017. istraživanja provedenog 2000./2001. po istoj metodologiji i na sličnome uzorku omogućilo je dijakronijsku usporedbu mentalnih karata zagrebačkih srednjoškolaca te donošenje zaključaka o kontinuitetu i promjenama u njihovim predodžbama o prostoru Europe.

Kako pokazuju rezultati istraživanja, Europa je na imaginativnoj karti obiju generacija mladih Zagrepčana jasno podijeljena na razvijeni Zapad i zaostali Istok. Obje su generacije percipirale Europu unutar binarnih opozicija: ekonomski prosperitet/siromaštvo, efikasnost/neefikasnost, modernost/ zaostalost i sl. Usprkos tom kontinuitetu u binarnom doživljavanju Europe, znatan porast statusa Rusije, vidljiv iz usporedbe podataka istraživanja 2000./2001. i 2016./2017., upućuje na određene pomake unutar te binarnosti. 
Podaci istraživanja također su pokazali da je, kada mladi razmišljaju o europskim migracijskim odredištima, kriterij pripadnosti tradicionalnim, povijesno uspostavljenim europskim kulturnim krugovima manje relevantan nego prije. Naime među najočitijim je promjenama u mentalnim kartama mladih relativan pad statusa mediteranskih zemalja, posebno Italije, kao poželjnoga migracijskog odredišta. Mediteranske zemlje (Grčka, Italija, Španjolska, Portugal, Monako, Malta i San Marino) činile su čak $70 \%$ zemalja čiji je status pao od 2001. do 2017. Nasuprot tome porastao je status sjevernih zemalja. Tako su Švedska, Norveška, Finska, Danska i Island te Irska zemlje koje su 2016./2017. kao migracijske destinacije bile popularnije nego na početku milenija.

Uzroke tendencije povećanja statusa sjevernih zemalja kao poželjnih migracijskih destinacija možemo iščitati iz odgovora na otvorena anketna pitanja. Naime kvalitativna obrada tih odgovora pokazuje da nova generacija svoj izbor najpoželjnijih zemalja u najvećoj mjeri temelji na ekonomskim značajkama zemalja destinacije, za razliku od prijašnje generacije, koja je pri svojoj visokoj evaluaciji poželjnih zemalja nešto češće navodila kulturne razloge od ekonomskih.

Na samome dnu rang-liste poželjnosti zemalja kao životnih odredišta u oba istraživanja našle su se zemlje pozicionirane na Balkanskome poluotoku. Upravo je u smještanju balkanskih zemalja, osobito Albanije, Srbije i Kosova, na samo dno liste prostornih preferencija jedna od najvećih sličnosti rezultata iz 2000./2001. i 2016./2017. Odgovori na otvorena anketna pitanja pokazuju izrazito negativan stav prema mogućnosti života u prostoru koji se percipira kao »balkanski«, i to kako zbog percipiranih slabih ekonomskih značajki tih zemalja tako i zbog izrazitih i očito stabilnih negativnih stereotipa.

\section{LITERATURA}

André, Y. i Bailly, A. (1998). Spatial representations of territories and the world, Prospects, 28 (2): 279-284, doi: https://doi.org/10.1007/bf02736950

Bailly, A. S., MacCabe, C. i Saarinen, T. (1995). Images of Francophone Countries and Francophone Images of the World, Geographica Helvetica, 1: 3-11, doi: https://doi. org/10.5194/gh-50-3-1995

Balija, M. (2019). Iseljavanje iz Hrvatske - razvojno i/ili sigurnosno pitanje?, Podravina: časopis za multidisciplinarna istraživanja, 18 (35): 105-121.

Gould, I., Kunovac, M. i Pripužić, D. (2018). Dynamics and determinants of emigration: the case of Croatia and the experience of new EU member states, Public sector economics, 42 (4): 415-447, doi: https://doi.org/10.3326/pse.42.4.3 
Gould, P. i White, R. (1986). Mental Maps. Boston: Allen \& Unwin.

Kirk, W. (1963). Problems of Geography, Geography, 48 (4): 357-371.

Kirk, W. (1989 [1952]). Historical Geography and the Concept of Behavioral Environment, u: F. W. Boal i D. N. Livingstone (ur.). The Behavioral Environment. Essays in Reflection, Application, and Re-evaluation. London - New York: Routledge, 18-30.

Lynch, K. (1960). The image of the city. Cambridge: The M.I.T. Press.

Saarinen, T. (1988). Centering of mental maps of the world, National Geographic Research, 4 (1): 112-127.

Saarinen, T. i MacCabe, C. (1995). World patterns of geographic literacy based on sketch map quality, The Professional Geographer, 47 (2): 196-204, doi: https://doi.org/10.1111/ j.0033-0124.1995.00196.x

Šakaja, L. (2001). Stereotipi mladih Zagrepčana o Balkanu: Prilog proučavanju imaginativne geografije, Revija za sociologiju, 32 (1-2): 27-37.

Šakaja, L. (2002). Mentalna karta Europe: vizura zagrebačkih srednjoškolaca, u: S. Mežnarić (ur.). Etničnost $i$ stabilnost Europe u 21. stoljeću - položaj i uloga Hrvatske. Zagreb: Jesenski i Turk, 103-129 i 417-422.

Šakaja, L. (2004). Images d'Europe vues de la Croatie, u: Y. Richard i A. Sanguin (ur.). L'Europe de l'Eest. Quinze ans après la chute du mur. Paris: L'Hartman, 295-308.

Šakaja, L. i Mesarić, R. (2001). Neke kognitivne pretpostavke migracija iz Hrvatske u druge europske zemlje, Hrvatski geografski glasnik, 63 (1): 43-65.

Todorova, M. (1996). The Construction of a Western Discourse of the Balkans, Etnološka tribina, 26: 7-25.

Todorova, M. (1997). Imagining the Balkans. New York: Oxford University Press.

Wright, J. K. (1947). Terrae Incognitae: The Place of Imagination in Geography, Annals of the Association of American Geographers, 37 (1): 1-15, doi: https://doi. org/10.1080/00045604709351940 


\section{Mental Map of Europe: Changes in Perception of Zagreb High-School Students (2000-2017)}

\section{Laura Šakaja}

\section{SUMMARY}

How do young people living in Europe see other European countries? Which countries do they consider interesting and for what reasons? Which European spaces are associated with negative stereotypes in their mental maps? What is the image of Europe created today by filtered information flows? This paper provides answers to these questions based on researching the mental maps of Europe held by high school students in Zagreb. The methodology used in the research is based on a methodological approach, described in detail in Peter Gould's and Rodney White's (1986) book "Mental Maps". It essentially consists of detecting European preference spaces by confronting respondents with a hypothetical, completely free choice of where they would like to live in Europe. The respondents were asked the following question: "Suppose you were free to choose which European country you would like to live in. Which countries would you prefer the most, and which would you never choose to live in?" Respondents were asked to score each country in a list of European countries, which, after being analysed by the statistical method of principal component analysis, made it possible to compile a ranking of European countries according to their desirability. The open-ended questions used in the survey provided insight into respondents' perceptions of individual countries and the stereotypes and prejudices associated with individual European spaces.

The answers to the open-ended questions also allowed the reconstruction of the criteria used by young people when evaluating individual European countries in terms of the desirability to live in them. The results suggest that young people determine the desirability hierarchy of countries based on arguments that can be generalised into eight basic criteria:

1. Job opportunities, economic conditions and the economic level of development. This group is distinguished by terms such as "rich country", "developed country", "developed economy", etc.

2. Political and social security and freedom. The most frequently mentioned phrases for this group were: "democratic country", "liberalism", "peaceful country", etc.

3. Culture, lifestyle, centrality and urban functions. Within this group, the most commonly mentioned words are: "culture", "rich history", "lifestyle", etc.

4. Ethnopsychological factors. When explaining the desire to live in certain countries, words such as "people", "folk", etc. are often used.

5. Nature. The most commonly mentioned factors in this group were: "natural beauty", "beautiful scenery", "climate".

6. Proximity. One of the desirability factors for living in certain countries was the close proximity to their homeland and the (in)ability to visit relatives. 
7. Personal reasons. This group included primarily arguments such as the existence of relatives or friends in a particular country, or knowledge of the language of the country.

8. Unspecified reasons, such as "not attractive", "strange", "I don't like it" or those with opposite sentiments: "nice country", "I like it", etc.

The survey was conducted in 2016-2017 as a repeat of a survey conducted in 2000 2001 (Šakaja, 2001; Šakaja and Mesarić, 2001; Šakaja, 2002). Repeating the research using the same methodology and a similar sample made it possible to make a diachronic comparison of the mental maps of high-school students in Zagreb and to draw conclusions regarding continuity and changes in their perceptions of European spaces.

As the research results show, Europe is clearly divided into the developed West and the backwards East on the imaginative map of both generations of young citizens of Zagreb. Both generations perceived Europe within binary oppositions: economic prosperity/poverty, efficiency/inefficiency, modernity/backwardness, etc. Despite this continuity in the binary perception of Europe, a significant increase in Russia's status, evident from the comparison of survey data from 2000/2001 and 2016/2017, indicates that some shifts within that binarity have occurred.

Research data also showed that when young people think about European migration destinations, the criterion of belonging to traditional, historically established European cultural circles is less relevant than before. In fact, among the most obvious changes in the mental maps of young people is the relative decline in the status of Mediterranean countries, especially Italy, as a desirable destination for migration. The countries of the Mediterranean (Greece, Italy, Spain, Portugal, Monaco, Malta, San Marino) represented $70 \%$ of the countries whose status deteriorated from 2001 to 2017. In contrast, the status of Northern countries improved. Sweden, Norway, Finland, Denmark, and Iceland, as well as Ireland, are countries that were more popular migration destinations in 2016/2017 than at the beginning of the millennium.

The open-ended questions from the survey point to the reasons why Northern countries improved their status as desirable migration destinations. The qualitative processing of these answers suggests that the new generation mainly bases its choice of the most desirable countries on the economic performance of the destination countries, unlike the earlier generation, which cited cultural reasons rather than economic ones when evaluating countries as highly desirable.

At the very bottom of the desirability ranking, both surveys contained countries located on the Balkan peninsula. The ranking of Balkan countries, especially Albania, Serbia, and Kosovo, at the bottom of the list of spatial preferences represents one of the greatest similarities between the 2000/2001 results and the 2016/2017 results. The answers to the open-ended survey questions show a markedly negative attitude towards the possibility of living in a space perceived as "Balkan", both because of the perceived poor economic performance of these countries and the pronounced and apparently stable negative stereotypes.

KEY WORDS: Europe, mental maps, spatial preferences 